\title{
Research on the Influencing Factors of Commercial Banks' Bad Loans under the New Normal of Economy
}

\author{
Lanyu Zhang*, Yilin Zang ${ }^{2}$, Chenxuan $\mathrm{Wu}^{3}$
}

Changwang College, Nanjing University of Information Science and Technology, Nanjing 210044, Jiangsu province, China. E-mail: 648743527@qq.com

Abstract: China is currently in a complex period of "three-phase superposition". Under the new normal of the economy Financial deleveraging has achieved certain results. However, the non-performing loan ratio of commercial banks has shown a continuous upward trend since 2015. The empirical results show that the degree of internalization of commercial banks, credit balances, and gross domestic product have a negative impact on the NPL ratio, and the cost-to-income ratio and leverage ratio have a positive impact on the NPL ratio. Therefore, commercial banks should vigorously develop digital technology, expand the scale of credit, use technological advantages to reduce costs, establish an appropriate level of leverage, and effectively reduce the non-performing loan ratio to improve the asset quality of commercial banks.

Keywords: Non-performing Loan Ratio; Multiple Linear Regression; Leverage Ratio; Commercial Bank

\section{Introduction}

Non-performing loans of commercial banks mainly refer to the transfer of funds by commercial banks to repay interest, but the users of funds fail to repay the principal and interest on time. According to the five-level loan classification theory, banks usually classify loans into normal loans, special mention loans, subprime loans, doubtful loans and loss loans. Non-performing loans mainly refer to subprime loans, doubtful loans and loss loans. As of the end of 2019 , the non-performing loan ratio of my country's commercial banks reached $1.86 \%$, the highest level since 2012 . At present, our country is in the period of "three-phase superposition", and the economy is entering a new normal development stage. Commercial banks' non-performing loans will directly affect the business conditions of commercial banks. Even worse, it will even bring the market economy back. Therefore, analyzing the influencing factors of non-performing loans and putting forward effective suggestions for reducing the rate of non-performing loans are of great significance for commercial banks to improve capital efficiency and promote the development of market economy.

\section{Literature Review}

Scholars at home and abroad have successively conducted in-depth studies on the influencing factors of non-performing loans of commercial banks. Cui Fucheng (2018) constructed a VAR model and analyzed the dynamic relationship between economic growth, monetary policy, total credit, corporate operating conditions, and non-performing loans through impulse response and variance decomposition methods. The results show that economic growth and monetary policy are negatively correlated with the non-performing loan rate in the short-term, while the

Copyright (C) 2021 Lanyu Zhang et al.

doi: $10.18686 /$ fm.v6i1.3269

This is an open-access article distributed under the terms of the Creative Commons Attribution Non-Commercial License

(http://creativecommons.org/licenses/by-nc/4.0/), which permits unrestricted non-commercial use, distribution, and reproduction in any medium,

provided the original work is properly cited. 
total credit volume and business conditions are negatively correlated with the non-performing loan rate in the long-term ${ }^{[1]}$. Gao Yi (2018) uses the sample data from 2014 to 2017 to establish a VAR model for the original value, volatility and GDP growth rate of non-performing loan rate to obtain the impact of non-performing loan ratio on economic fluctuations. The results show that the influence of economic fluctuations on the NPL ratio decreases over time, and the NPL ratio has a feedback effect on economic fluctuations ${ }^{[2]}$. Jin Xinxue (2018) used factor analysis and linear regression models to analyze the factors of non-performing loans of commercial banks. The research shows that: total economic volume, economic benefits, trade development and investment development are all negatively correlated with non-performing loans ${ }^{[3]}$. Sun Ming (2020) established a panel analysis model of multiple regression by using the panel data analysis method from 2008 to 2017. The results show that the higher the unemployment rate, the higher the non-performing loan rate of commercial banks, and the higher the inflation rate, the non-performing commercial banks. The higher the loan rate, and the larger the bank capital are, the lower the consideration of non-performing loans of commercial banks will be. The faster the GDP growth, the lower the non-performing loan rate of commercial banks ${ }^{[4]}$.

It can be seen from previous scholars' research that most scholars study the causes of non-performing loan rates based on macro and micro factors. Macro indicators include GDP, money supply, etc., and micro indicators include total bank credit, business efficiency, etc. With the increase of China's financial asset bubble, in 2016, the regulatory authorities proposed "financial deleveraging" related policies. Although they have made some achievements, the leverage ratio is still an important factor in the risk of China's commercial banks. In addition, with the rapid rise of Internet finance, and the development of Internet technology, especially the development of Internet technology of commercial banks, has had an important impact on the operating efficiency and profitability of commercial banks. Therefore, this paper combines the existing research results, introduces this article introduces the two indicators of commercial banks' internalization degree and leverage ratio to construct a multiple regression model to empirically analyze the factors affecting the non-performing loan rate of commercial banks ${ }^{[5]}$.

\section{Research Design}

\subsection{Data Sources}

Select 48 sets of quarterly data from 2008 to 2019 as the sample. Among them, the data of commercial banks' Internet level, cost-income ratio, leverage ratio, credit balance, gross domestic product, and non-performing loan ratio come from the National Bureau of Statistics, China Banking Regulatory Commission, and the People's Republic of China. The leverage ratio is obtained by selecting the leverage ratio of 30 listed commercial banks in my country and taking the weighted average median according to time, which represents the leverage ratio of China's cial banks.

\subsection{Model Design}

Based on the existing research, this paper takes the level of commercial banks' internalization, cost-to-income ratio, leverage ratio, credit balance and GDP as explanatory variables, and non-performing loan ratio as the explanatory variables, and constructs a multiple linear regression model as follows:

$$
N P L_{t}=\alpha_{0}+\alpha_{1} \text { Ioc }_{t}+\alpha_{2} \text { Cir }_{t}+\alpha_{3} \operatorname{Lev}_{t}+\alpha_{4} \text { Cdm }_{t}+\alpha_{5} G d p_{t}+\varepsilon_{t}
$$

Among them, Ioc is the degree of internetization of commercial banks, Cir is the cost-to-income ratio, Lev is the leverage ratio, $\mathrm{Cdm}$ is the credit balance, Gdp is the gross domestic product, and NPL is the non-performing loan ratio, $\varepsilon$ is the error disturbance term.

\section{Empirical Analysis}

It can be seen from the regression analysis results in Table 1 that the regression coefficient between the degree of commercial banks' Internetization and the non-performing loan rate is -0.588 at a significant level of $1 \%$, which indicates that the development of commercial banks' Internetization has effectively reduced the non-performing loan ratio. 
On the one hand, the development of Internet technology in commercial banks has broadened ing business channels and improved risk management capabilities through technology management and risk control. On the other hand, the development of Internet technology has brought about an increase in credit investigation methods, which has reduced the number of credit reporting methods to some extent. Therefore, the faster the internet development of commercial banks, the lower the probability of non-performing loans.

Table 1. Parameter estimation result

\begin{tabular}{|l|l|l|}
\hline Variable & Coefficient & VIF \\
\hline Ioc & $\begin{array}{l}-0.588^{* * *} \\
(-4.429)\end{array}$ & 1.76 \\
\hline Cir & $\begin{array}{l}0.200^{* *} \\
(0.0409)\end{array}$ & 1.94 \\
\hline Lev & $\begin{array}{l}0.527^{* * *} \\
(2.0128)\end{array}$ & 1.28 \\
\hline Cdm & $\begin{array}{l}-0.311^{* *} \\
(-3.6392)\end{array}$ & 1.81 \\
\hline Gdp & $\begin{array}{l}-0.454^{* * *} \\
(-0.2848)\end{array}$ & 2.98 \\
\hline $\bar{R}^{2}$ & 0.9716 & \\
\hline F & $3.4290^{* * *}$ & \\
\hline
\end{tabular}

Note: “*” indicates the significance level of the variable relationship is $10 \%$, “**” indicates the significance level of the variable relationship is $5 \%$, and “***" indicates the variable relationship level is $1 \%$.

The regression coefficient between the cost-to-income ratio and the non-performing loan ratio at the 5\% level of significance is 0.2002 , indicating that the greater the proportion of commercial banks' costs, the higher the probability of non-performing loans. Commercial banks obtain funds through higher costs, their liquidity will be negatively affected, thereby reducing asset quality and increasing the probability of non-performing loans. The regression coefficient between the leverage ratio and the non-performing loan ratio at the $1 \%$ significance level is 0.527 , indicating that high leverage will lead to an increase of the non-performing loan ratio. If the leverage ratio of commercial banks is too high, the trustee's cost will increase, and many companies will be unbearable Heavy burdens make it difficult to repay loans, which leads to the occurrence of non-performing loan rates. The regression coefficient between the credit balance and the non-performing loan ratio at the $5 \%$ level of significance is -0.311 , indicating that the larger the credit balance, the smaller the probability of occurrence of non-performing loans; the larger the credit balance, the less non-performing loans will be allocated to reduce non-performing loans. The regression coefficient between GDP and non-performing loan ratio is -0.454 at the significance level of $1 \%$, indicating that the larger the GDP, the smaller the non-performing loan ratio. With the increase in GDP, the demand for social investment will increase, enterprises can obtain more financing and investment channels, and their profitability will increase, thus reducing the non-performing loan ratio of 6 billion dollars ${ }^{[6]}$.

\section{Robustness Test}

In order to ensure the robustness of the research results, this article replaces the main variables as follows: the proportion of five categories of loans in total loans is used to measure the share of non-performing loans, and the newly selected variable measurement indicators are brought into the model for re-regression. The results of regression are shown in the table2. After replacing the indicators, the regression results are obtained. The degree of commercial banks' own internetization, credit balance, and GDP are negatively correlated with the share of non-performing loans, and the 
cost-to-income ratio and leverage ratio are positively correlated with the share of non-performing loans. Consistently, it shows that the research conclusions of this article are reliable and robust.

Table 2. Robustness test results

\begin{tabular}{|c|c|}
\hline Variable & Coefficient \\
\hline Ioc & $\begin{array}{l}-0.498^{* * *} \\
(-2.9120)\end{array}$ \\
\hline Cir & $\begin{array}{l}0.239^{* *} \\
(0.8088)\end{array}$ \\
\hline Lev & $\begin{array}{l}0.446^{* * *} \\
(1.7922)\end{array}$ \\
\hline $\mathrm{Cdm}$ & $\begin{array}{l}-0.274^{* *} \\
(-3.6548)\end{array}$ \\
\hline Gdp & $\begin{array}{l}-0.2025^{* * *} \\
(-5.6518)\end{array}$ \\
\hline $\bar{R}^{2}$ & 0.951 \\
\hline $\mathrm{F}$ & $0.387^{* * *}$ \\
\hline
\end{tabular}

\section{Conclusions and Recommendations}

This paper uses multiple regression methods to study the influencing factors of the non-performing loan rate of commercial banks, and the following conclusions are obtained from the regression results: First, the degree of internetization of commercial banks, credit balance and GDP have a significant negative impact on the non-performing loan rate. Second, the impact of cost-to-income ratio and leverage ratio on the NPL ratio is significantly positive ${ }^{[7]}$.

Based on the above conclusions of the study, the following recommendations are made: First, in the face of the rapid development of the "Internet +" model, commercial banks should actively develop digital technology, integrate digital technology with commercial banking business, strengthen bank risk systems, and improve taxation Credit system, expand online banking business, and innovate financial products to keep up with the rapid development of modern Internet. Second, effectively control the operating costs of commercial banks, expand the scale of commercial bank lending, and vigorously develop intermediary businesses. Business personnel should actively expand relevant businesses in order to effectively reduce the probability of non-performing loans. Third, it guides the appropriate level of leverage. Too low leverage will reduce the profits of commercial banks and lower their profitability. Indirectly reducing its willingness to lend also narrows corporate financing channels and increases credit risk. An excessively high leverage ratio will increase the operating costs of financing companies, making the company heavily indebted, making it difficult to maintain production, and ultimately leading to bankruptcy and increasing the probability of non-performing loans. Therefore, commercial banks should establish an appropriate leverage ratio to reduce corporate financing costs under the premise of ensuring profits and achieve a win-win situation ${ }^{[8]}$.

\section{References}

1. Cui F, Hao T. The causes and countermeasures of non-performing loans of my country's commercial banks under the new economic normal. Economic System Reform 2018; (4): 139 - 145.

2. Gao Y. Research on the dynamic relationship between my country's economic fluctuations and non-performing loans in the banking industr. Beijing: Capital University of Economics and Business 2018.

3. Jin X. An Empirical Analysis of Non-performing Loans of Commercial Banks under the New Normal of Economy. Journal of Xi Chang College 2018; (6): 78 - 80. 
4. Sun M, Zhao L. Analysis of the influencing factors of non-performing loans of my country's commercial banks. Economic Research Guide 2020; (5): 127 - 133.

5. Xie Y. An Empirical Analysis of the Main Influencing Factors of Domestic Tourism Income — Based on the Multiple Linear Regression Mode. Journal of Beijing Institute of Graphic Communication 2020; (1): 64 - 66.

6. Jiang C, Jiang J. The influence of political geography and bank non-performing loans on corporate leverage ratio. Financial Observer 2018; (8): 109 - 114.

7. Zhang H, Geng H. An Empirical Analysis of the Influencing Factors of Non-Performing Loans in my country's Commercial Banks. Economic Perspective 2016; (6): 57 - 67.

8. Wang T, Zhu J. Research on the influencing factors of profitability of commercial banks based on linear regression analysis. Journal of Science of Normal University 2018; (8): 15 - 18. 